\title{
Butterflies (Lepidoptera: Hesperioidea, Papilionoidea) of the Kampinos National Park and its buffer zone
}

\author{
Izabela DZIEKAŃSKA* and Marcin SIELEZNIEW** \\ *Department of Applied Entomology, Warsaw University of Life Sciences, Nowoursynowska 159, 02-776, Warszawa, \\ Poland; e-mail: e-mail: i.dziekanska@wp.pl \\ **Department of Invertebrate Zoology, Institute of Biology, University of Bialystok, Swierkowa 20B, 15-950 Bialystok, \\ Poland; e-mail:marcins@uwb.edu.pl
}

\begin{abstract}
Kampinos National Park is the second largest protected area in Poland and therefore a potentially important stronghold for biodiversity in the Mazovia region. However it has been abandoned as an area of lepidopterological studies for a long time. A total number of 80 butterfly species were recorded during inventory studies (2005-2008), which proved the occurrence of 80 species $(81.6 \%$ of species recorded in the Mazovia voivodeship and about half of Polish fauna), including 7 from the European Red Data Book and 15 from the national red list ( 8 protected by law). Several xerothermophilous species have probably become extinct in the last few decades (Colias myrmidone, Pseudophilotes vicrama, Melitaea aurelia, Hipparchia statilimus, H. alcyone), or are endangered in the KNP and in the region (e.g. Maculinea arion, Melitaea didyma), due to afforestation and spontaneous succession. Higrophilous butterflies have generally suffered less from recent changes in land use, but action to stop the deterioration of their habitats is urgently needed. Lycaena dispar, Maculinea teleius and $M$. alcon are still quite widespread but $L$. helle and Euphydras aurinia were recorded on single sites only. However, Maculinea nausithous was observed only in 2005 and has probably just disappeared from the KNP. Despite the aforementioned losses, the Kampinos Forest deserves to be added to the list of the Prime Butterfly Areas in Europe.
\end{abstract}

Key words: butterflies, biodiversity, Kampinos National Park, fauna of Poland, endangered species

\section{INTRODUCTION}

Butterflies (Papilionoidea and Hesperiodea) belong to the best studied group of invertebrates in Poland. Data about their distribution appear in many papers concerning particular parts of the country, especially national and landscape parks, nature reserves, and other areas which are attractive as far as nature is concerned, as well as in the vicinity of cities (e.g. Klimczuk \& Twerd 2000, Winiarska 2001, Sielezniew 2001, Sielezniew \& Sachanowicz 2003, Kudla \& Wojtusiak 2004, Palik et al. 2005). For many older references see Buszko \& Nowacki (2000).

However, although the Kampinos National Park is the second largest protected area in Poland and neighbours the capital city and scientific centres, it has been long abandoned as an area of lepidopterological study. The eastern parts were explored by Patryn (1947), who included some data in his checklist of lepidopterans collected in the vicinity of Warsaw. However, only 39 species from sites presently encompassed by the KNP are mentioned in this paper, and even some common and widespread butterflies are missing. There are also records of 57 species from $10 \mathrm{~km}$ UTM squares overlapping with that area included in 'A Distribution Atlas of Butterflies in Poland 1986-1995' (Buszko 1997).

Here we present results of our inventory work on butterflies, which was initiated only in 2005, aiming to fill at least in part this severe and embarrassing gap. 


\section{STUDY AREA}

Kampinos National Park was established in 1959 and its area extends over 38544 ha. It was included in the NATURA 2000 network and it was also designed as a Biosphere reserve UNESCO MaB. The park together with its buffer zone (37 $756 \mathrm{ha}$ ), protects part of the former Kampinos Forest, lying within the alluvial terraces of the former ice-marginal valley of the Vistula River. The climate of the area is moderate with an average annual temperature of $7.8^{\circ} \mathrm{C}$, a mean yearly precipitation of $529.6 \mathrm{~mm}$ and a growing season of 185 days. The Park borders the city of Warsaw (Fig. 1), with approx 1.8 million inhabitants.
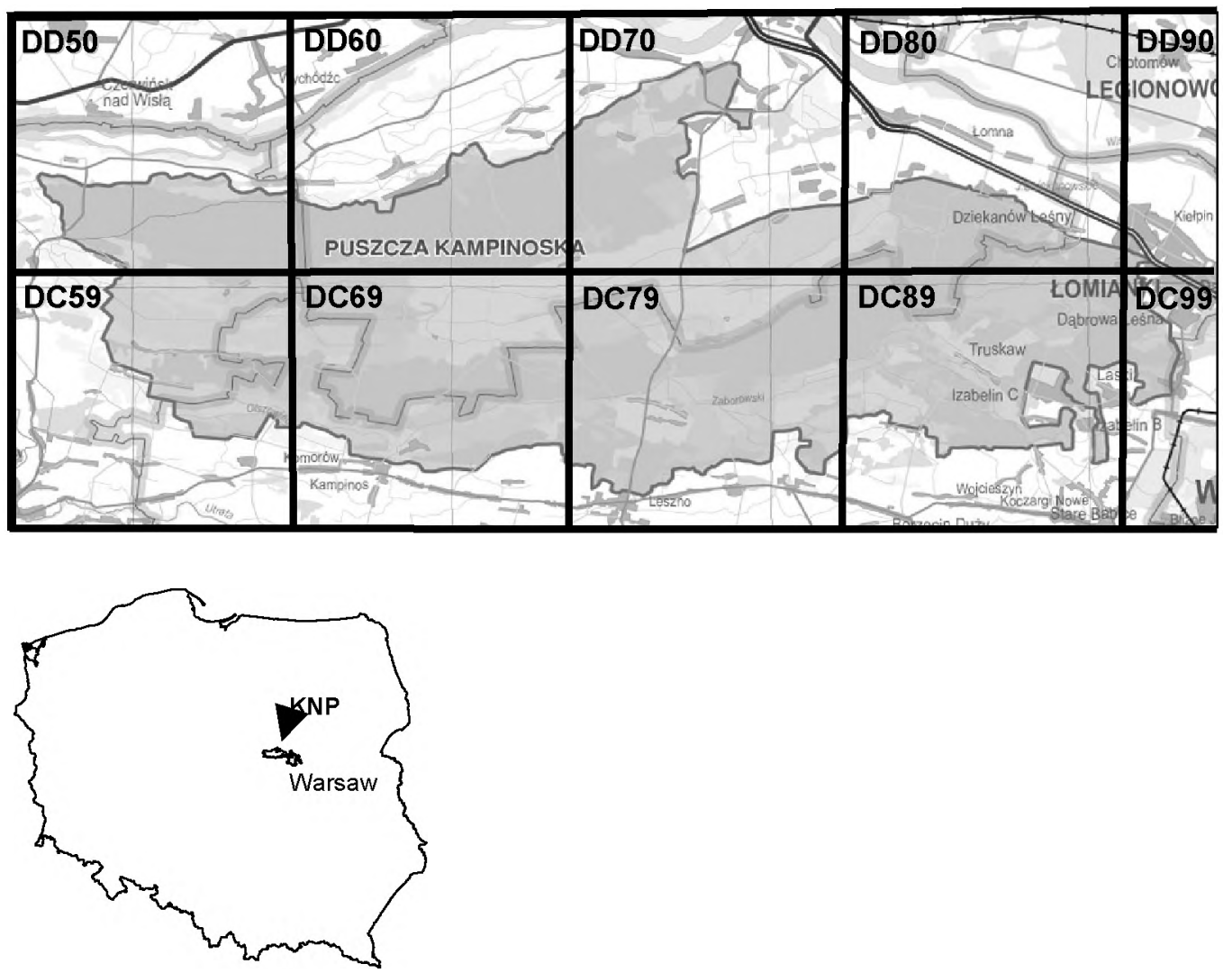

Fig. 1. Outline map of the Kampinos National Park with plotted 10-km UTM grid system.

Although the land surrounding the Kampinos Forest was early colonized by humans, due to its very fertile soils, the area of today's national park was inhabited quite late. The inland dunes, with their poor sands, did not attract agriculture, while mires and swamps restricted penetration of the inner parts. The first immigrants arrived around 1750 and settled on the most elevated ground. Their major occupation was clearing the forests. The settlers introduced new land management practices, with regular systems of drainage ditches and dikes protecting houses from flooding. Thus, two types of farming developed parallel in the Park's territory: an extensive and smaller scale type inside the forests on fens and poor sandy soils, and more intensive, with larger portions closer to the river, on richer alluvial soils (Heymanowski 1966).

Two major drainage schemes were carried out in the second half of the $19^{\text {th }}$ century and then in the 1950's, resulting in the degradation of wetlands. Even the establishment of the 
national park did not stop this process immediately. At the moment those areas are still excessively desiccated and groundwater level drop is one of the main problems in the park. The negative impact of drainage on the whole area was one of main reasons for initiating the land purchase process by the park. Although most of small villages situated in the depths of the forest were displaced, most of the drainage ditches are still not blocked (Michalska-Hejduk 2006). Moreover the majority of the bought land has been afforested, as the meadows were, until recently, little recognized as the real value of the area.

Forests cover about 70\% of the area and Pinus silvestris L. is the dominant tree. Open areas encompass a mosaic of aquatic and semi-aquatic vegetation types, sedge-beds, rich and poor fens, wet meadows, heathland and sandy xerothermic grasslands. This diversity is related to two types of dominating and contrasting landscapes characteristic to the Kampinos Forest i.e. wetlands and dunes, as well as to past management practices (Michalska-Hejduk 2001, Matysiak 2007).

Dry heathland Arctostaphylo-Callunetum and a sandy vegetation of Spergulo morisoniiCorynephoretum, Silene otitis-Festucetum and Festuco psammophilae-Koelerietum glaucae cover the slopes of the dunes. Occasional grazing was the traditional form of management. In mesic habitats, Arrhenatheretum elatioris is a frequently encountered type of meadow. However, in the past, litter meadows (Molinion) were considered the most widespread meadow community of the Kampinos area (Kobendza 1930). Following abandonment, they belong to

the fastest declining types at the moment and the tall herbs Filipendulion are the dominant vegetation type. Sedge-moss fens Scheuchzerio-Caricetea and Phragmitetea occur locally in groundwater seepage sites although they have declined considerably due to drainage.

\section{MATERIAL AND METHODS}

Observations were carried out in April-September 2005-2008. Different parts of the KNP and its close surroundings were explored with differing intensity. Special attention was paid to places commonly known as the most attractive for butterflies, i.e. forest roads, clearings, heathland, meadows and fens. Gathered data were aligned to a $10-\mathrm{km}$ UTM grid system (Fig. 1) and for every square a separate list was prepared. The most regular and intensive studies were performed in squares DC 79 and DC 89 where transect routes were fixed and butterflies were counted according to a method described by Pollard \& Yates (1993). The detailed data collected on phenology, and the habitat preferences of some species are outside the main scope of this paper and will be published elsewhere.

Butterflies were identified in the field and a few specimens were collected, for Leptidea reali Reiss. only, as preparation of genitalia is necessary for species determination. Nomenclature and systematic order used by Buszko \& Masłowski (2008) were applied in our arrangements.

A list of rare and threatened species in the KNP was prepared on the basis of collected data using categories applied by Buszko \& Nowacki (2002) adapted to the local scale.

\section{RESULTS AND DISCUSSION}

A total number of 80 butterfly species (Table 1) i.e. about half of Polish fauna (Buszko \& Maslowski 2008) and 81.6\% of species recorded in the Mazovia voivodeship after 1960 (Buszko \& Nowacki 2000, Winiarska 2003) has been recorded during the presented studies in the Kampinos Forest. The last figure, especially, is relatively high compared with other previously studied lowland areas in the Podlasie region i.e. Białowieża Forest: 114 species (Buszko et al. 1996), Biebrza National Park: 93 species (Frąckiel 1999), Knyszyn Forest: 94 species (Klimczuk \& Twerd 2000), Narew National Park: 40 species (Winiarska 2001), Romincka Forest: 67 species (Sielezniew \& Sachanowicz 2003). 
Table 1. Checklist of butterflies recorded in the KNP and in its buffer zone between 2005 and 2008 according to UTM squares.

\begin{tabular}{|c|c|c|c|c|c|c|c|c|c|c|}
\hline \multirow{2}{*}{ No. } & \multirow{2}{*}{ Butterfly species } & \multicolumn{9}{|c|}{ UTM squares $(10 \times 10 \mathrm{~km})$} \\
\hline & & DC59 & DC69 & DC79 & DC89 & DC99 & DD50 & DD60 & DD70 & DD80 \\
\hline 1 & 2 & 3 & 4 & 5 & 6 & 7 & 8 & 9 & 10 & 11 \\
\hline 1 & $\begin{array}{c}\text { Hesperiidae } \\
\text { Erynnis tages (Linnaeus, 1758) }\end{array}$ & $\mathrm{x}$ & $\mathrm{x}$ & $\mathrm{x}$ & $\mathrm{x}$ & $\mathrm{x}$ & & & $\mathrm{x}$ & $\mathrm{x}$ \\
\hline 2 & Carcharodus alceae (Esper, 1780) & & & $\mathrm{x}$ & & & & & & \\
\hline 3 & Pyrgus malvae (Linnaeus, 1758) & $\mathrm{x}$ & $\mathrm{x}$ & $\mathrm{x}$ & $\mathrm{x}$ & $\mathrm{x}$ & $\mathrm{x}$ & & $\mathrm{x}$ & \\
\hline 4 & Heteropterus morpheus (Pallas, 1771) & $\mathrm{x}$ & $\mathrm{x}$ & $\mathrm{x}$ & $\mathrm{x}$ & $\mathrm{x}$ & & & $\mathrm{x}$ & $\mathrm{x}$ \\
\hline 5 & Thymelicus lineola (Ochsenheimer, 1808) & $\mathrm{x}$ & $\mathrm{x}$ & $\mathrm{x}$ & $\mathrm{x}$ & $\mathrm{x}$ & $\mathrm{x}$ & $\mathrm{x}$ & $\mathrm{x}$ & $\mathrm{x}$ \\
\hline 6 & Thymelicus sylvestris (Poda, 1761) & $\mathrm{x}$ & $\mathrm{x}$ & $\mathrm{x}$ & $\mathrm{x}$ & $\mathrm{x}$ & $\mathrm{x}$ & $\mathrm{x}$ & $\mathrm{x}$ & $\mathrm{x}$ \\
\hline 7 & Hesperia comma (Linnaeus, 1758) & & $\mathrm{x}$ & $\mathrm{x}$ & $\mathrm{x}$ & $\mathrm{x}$ & & & $\mathrm{x}$ & \\
\hline 8 & Ochlodes sylvamus (Esper, 1777) & $\mathrm{x}$ & $\mathrm{x}$ & $\mathrm{x}$ & & $\mathrm{x}$ & $\mathrm{x}$ & $\mathrm{x}$ & $\mathrm{x}$ & $\mathrm{x}$ \\
\hline & Papilionidae & & & & & & & & & \\
\hline 9 & Iphiclides podalirius (Linnaeus, 1758) & & $\mathrm{x}$ & & $\mathrm{x}$ & $\mathrm{x}$ & & & & \\
\hline 10 & $\begin{array}{c}\text { Papilio machaon Linnaeus, } 1758 \\
\text { Pieridae }\end{array}$ & $\mathrm{x}$ & $\mathrm{x}$ & $\mathrm{x}$ & $\mathrm{x}$ & $\mathrm{x}$ & & & $\mathrm{x}$ & $\mathrm{x}$ \\
\hline 11 & Leptidea reali Reissinger, 1989 & $\mathrm{x}$ & $\mathrm{x}$ & $\mathrm{x}$ & $\mathrm{x}$ & $\mathrm{x}$ & $\mathrm{x}$ & $\mathrm{x}$ & $\mathrm{x}$ & $\mathrm{x}$ \\
\hline 12 & Anthocharis cardamines (Linnaeus, 1758) & $\mathrm{x}$ & $\mathrm{x}$ & $\mathrm{x}$ & $\mathrm{x}$ & $\mathrm{x}$ & $\mathrm{x}$ & $\mathrm{x}$ & $\mathrm{x}$ & $\mathrm{x}$ \\
\hline 13 & Pieris brassicae (Linnaeus, 1758) & $\mathrm{x}$ & $\mathrm{x}$ & $\mathrm{x}$ & $\mathrm{x}$ & $\mathrm{x}$ & $\mathrm{x}$ & $\mathrm{x}$ & $\mathrm{x}$ & $\mathrm{x}$ \\
\hline 14 & Pieris rapae (Linnaeus, 1758 ) & $\mathrm{x}$ & $\mathrm{x}$ & $\mathrm{x}$ & $\mathrm{x}$ & $\mathrm{x}$ & $\mathrm{x}$ & $\mathrm{x}$ & $\mathrm{x}$ & $\mathrm{x}$ \\
\hline 15 & Pieris napi (Linnaeus, 1758) & $\mathrm{x}$ & $\mathrm{x}$ & $\mathrm{x}$ & $\mathrm{x}$ & $\mathrm{x}$ & $\mathrm{x}$ & $\mathrm{x}$ & $\mathrm{x}$ & $\mathrm{x}$ \\
\hline 16 & Pontia edusa (Fabricius, 1777) & $\mathrm{x}$ & $\mathrm{x}$ & $\mathrm{x}$ & $\mathrm{x}$ & $\mathrm{x}$ & & & $\mathrm{x}$ & \\
\hline 17 & Colias croceus (Fourcroy, 1785) & & $\mathrm{x}$ & $\mathrm{x}$ & & & & & & \\
\hline 18 & Colias hyale (Linnaeus, 1758) & & $\mathrm{x}$ & $\mathrm{x}$ & $\mathrm{x}$ & $\mathrm{x}$ & & & $\mathrm{x}$ & \\
\hline 19 & $\begin{array}{c}\text { Gonepteryx rhamni (Linnaeus, 1758) } \\
\text { Lycaenidae }\end{array}$ & $\mathrm{x}$ & $\mathrm{x}$ & $\mathrm{x}$ & $\mathrm{x}$ & $\mathrm{x}$ & $\mathrm{x}$ & $\mathrm{x}$ & $\mathrm{x}$ & $\mathrm{x}$ \\
\hline 20 & Lycaena phlaeas (Linnaeus, 1761) & $\mathrm{x}$ & $\mathrm{x}$ & $\mathrm{x}$ & $\mathrm{x}$ & $\mathrm{x}$ & & & $\mathrm{x}$ & $\mathrm{x}$ \\
\hline 21 & Lycaena helle (Denis et Schiffermüller, 1775) & & & $\mathrm{x}$ & & & & & & \\
\hline 22 & Lycaena dispar (Haworth, 180 ) & $\mathrm{x}$ & $\mathrm{x}$ & $\mathrm{x}$ & $\mathrm{x}$ & $\mathrm{x}$ & & & $\mathrm{x}$ & $\mathrm{x}$ \\
\hline 23 & Lycaena tityrus (Poda, 1761) & $\mathrm{x}$ & $\mathrm{x}$ & $\mathrm{x}$ & $\mathrm{x}$ & $\mathrm{x}$ & & $\mathrm{x}$ & $\mathrm{x}$ & $\mathrm{x}$ \\
\hline 24 & Lycaena alciphron (Rottemburg, 1775) & $\mathrm{x}$ & $\mathrm{x}$ & $\mathrm{x}$ & $\mathrm{x}$ & $\mathrm{x}$ & & & & $\mathrm{x}$ \\
\hline 25 & Lycaena hippothoe (Linnaeus, 1761) & & $\mathrm{x}$ & $\mathrm{x}$ & $\mathrm{x}$ & $\mathrm{x}$ & & & & $\mathrm{x}$ \\
\hline 26 & Thecla betulae (Linnaeus, 1758) & $\mathrm{x}$ & & $\mathrm{x}$ & $\mathrm{x}$ & $\mathrm{x}$ & & & $\mathrm{x}$ & \\
\hline 27 & Neozephyrus quercus (Linnaeus, 1758) & & $\mathrm{x}$ & $\mathrm{x}$ & & & & & & \\
\hline 28 & Callophrys rubi (Linnaeus, 1758) & $\mathrm{x}$ & $\mathrm{x}$ & $\mathrm{x}$ & $\mathrm{x}$ & $\mathrm{x}$ & $\mathrm{x}$ & $\mathrm{x}$ & $\mathrm{x}$ & $\mathrm{x}$ \\
\hline 29 & Satyrium w-album (Knoch, 178) & & & $\mathrm{x}$ & $\mathrm{x}$ & & & & & \\
\hline 30 & Satyrium pruni (Linnaeus, 1758 ) & & $\mathrm{x}$ & & & $\mathrm{x}$ & & & & \\
\hline 31 & Satyrium spini (Denis et Schiffermüller, 1775) & & & & $\mathrm{x}$ & & & & $\mathrm{x}$ & \\
\hline 32 & Satyrium ilicis (Esper, 1779) & & & & $\mathrm{x}$ & $\mathrm{x}$ & & & & \\
\hline 33 & Cupido minimus (Fuessly, 1775) & & & & & $\mathrm{x}$ & & & & \\
\hline 34 & Cupido argiades (Pallas, 1771) & $\mathrm{x}$ & $\mathrm{x}$ & $\mathrm{x}$ & $\mathrm{x}$ & $\mathrm{x}$ & & & $\mathrm{x}$ & $\mathrm{x}$ \\
\hline 35 & Celastrina argiolus (Linnaeus, 1758) & $\mathrm{x}$ & $\mathrm{x}$ & $\mathrm{x}$ & $\mathrm{x}$ & $\mathrm{x}$ & $\mathrm{x}$ & $\mathrm{x}$ & $\mathrm{x}$ & $\mathrm{x}$ \\
\hline 36 & Maculinea arion (Linnaeus, 1758) & & & & $\mathrm{x}$ & & & & & \\
\hline 37 & Maculinea teleius (Bergstraässer, 1779) & $\mathrm{x}$ & $\mathrm{x}$ & $\mathrm{x}$ & $\mathrm{x}$ & & & & $\mathrm{x}$ & $\mathrm{x}$ \\
\hline 38 & Maculinea nausithous (Bergsträsser, 1779) & & & $\mathrm{x}$ & & & & & & \\
\hline 39 & Maculinea alcon (Denis et Schiffermüller, 1775) & $\mathrm{x}$ & & $\mathrm{x}$ & $\mathrm{x}$ & $\mathrm{x}$ & & & $\mathrm{x}$ & \\
\hline 40 & Plebejus argus (Linnaeus, 1758) & & & & $\mathrm{x}$ & & & & & \\
\hline 41 & Plebejus idas (Linnaeus, 1761) & & & $\mathrm{x}$ & $\mathrm{x}$ & & & & $\mathrm{x}$ & \\
\hline 42 & Aricia agestis (Denis et Schiffermüller, 1775) & & $\mathrm{x}$ & $\mathrm{x}$ & & & & & & \\
\hline 43 & Polyommatus semiargus (Rottemburg, 1775) & $\mathrm{x}$ & & $\mathrm{x}$ & $\mathrm{x}$ & $\mathrm{x}$ & & & & $\mathrm{x}$ \\
\hline 44 & Polyommatus amandus (Schneider, 1792) & $\mathrm{x}$ & & $\mathrm{x}$ & $\mathrm{x}$ & $\mathrm{x}$ & & & $\mathrm{x}$ & $\mathrm{x}$ \\
\hline 45 & Polyommatus icarus (Rottemburg, 1775) & $\mathrm{x}$ & $\mathrm{x}$ & $\mathrm{x}$ & $\mathrm{x}$ & $\mathrm{x}$ & $\mathrm{x}$ & $\mathrm{x}$ & $\mathrm{x}$ & $\mathrm{x}$ \\
\hline 46 & Polyommatus coridon (Poda, 1761) & & & & & $\mathrm{x}$ & & & & \\
\hline
\end{tabular}


Butterflies of the Kampinos N. P.

\begin{tabular}{|c|c|c|c|c|c|c|c|c|c|c|}
\hline 1 & 2 & 3 & 4 & 5 & 6 & 7 & 8 & 9 & 10 & 11 \\
\hline & Nymphalidae & & & & & & & & & \\
\hline 47 & Argynnis paphia (Linnaeus, 1758) & $\mathrm{x}$ & $\mathrm{x}$ & $\mathrm{x}$ & $\mathrm{x}$ & $\mathrm{x}$ & & $\mathrm{x}$ & & $\mathrm{x}$ \\
\hline 48 & Argymmis aglaja (Linnaeus, 1758) & $\mathrm{x}$ & $\mathrm{x}$ & $\mathrm{x}$ & $\mathrm{x}$ & $\mathrm{x}$ & & & $x$ & $\mathrm{x}$ \\
\hline 49 & Argynnis adippe (Denis et Schiffermüller, 1775) & & & & $\mathrm{x}$ & & & & & \\
\hline 50 & Argynnis laodice (Pallas, 1771) & & & & $\mathrm{x}$ & & & & & \\
\hline 51 & Issoria lathonia (Linnaeus, 1758) & $x$ & $x$ & $x$ & $\mathrm{x}$ & $x$ & $x$ & $x$ & $x$ & $x$ \\
\hline 52 & Brenthis ino (Rottemburg, 1775) & $\mathrm{x}$ & $\mathrm{x}$ & $\mathrm{x}$ & $\mathrm{x}$ & $\mathrm{x}$ & & & $\mathrm{x}$ & $x$ \\
\hline 53 & Boloria selene (Denis et Schiffermüller, 1775) & $\mathrm{x}$ & $\mathrm{x}$ & $\mathrm{x}$ & $\mathrm{x}$ & $\mathrm{x}$ & & & $\mathrm{x}$ & $\mathrm{x}$ \\
\hline 54 & Boloria dia (Linnaeus, 1767) & $\mathrm{x}$ & $\mathrm{x}$ & $\mathrm{x}$ & $\mathrm{x}$ & $\mathrm{x}$ & & $\mathrm{x}$ & & \\
\hline 55 & Vanessa atalanta (Linnaeus, 1758) & $\mathrm{x}$ & $\mathrm{x}$ & $\mathrm{x}$ & $\mathrm{x}$ & $\mathrm{x}$ & $x$ & $\mathrm{x}$ & $\mathrm{x}$ & $\mathrm{x}$ \\
\hline 56 & Vanessa cardui (Linnaeus, 1758) & $\mathrm{x}$ & $\mathrm{x}$ & $\mathrm{x}$ & $\mathrm{x}$ & $\mathrm{x}$ & & & & $\mathrm{x}$ \\
\hline 57 & Inachis io (Linnaeus, 1758) & $\mathrm{x}$ & $\mathrm{x}$ & $\mathrm{x}$ & $\mathrm{x}$ & $\mathrm{x}$ & $\mathrm{x}$ & $\mathrm{x}$ & $\mathrm{x}$ & $\mathrm{x}$ \\
\hline 58 & Aglais urticae (Linnaeus, 1758) & $\mathrm{x}$ & $\mathrm{x}$ & $\mathrm{x}$ & $\mathrm{x}$ & $\mathrm{x}$ & $\mathrm{x}$ & $\mathrm{x}$ & $\mathrm{x}$ & $\mathrm{x}$ \\
\hline 59 & Polygonia c-album (Linnaeus, 1758) & $\mathrm{x}$ & $\mathrm{x}$ & $\mathrm{x}$ & $\mathrm{x}$ & $\mathrm{x}$ & $\mathrm{x}$ & $\mathrm{x}$ & $\mathrm{x}$ & $\mathrm{x}$ \\
\hline 60 & Araschnia levana (Linnaeus, 1758) & $\mathrm{x}$ & $\mathrm{x}$ & $\mathrm{x}$ & $\mathrm{x}$ & $\mathrm{x}$ & $\mathrm{x}$ & $\mathrm{x}$ & $\mathrm{x}$ & $\mathrm{x}$ \\
\hline 61 & Nymphalis antiopa (Linnaeus, 1758) & $\mathrm{x}$ & $\mathrm{x}$ & $\mathrm{x}$ & $\mathrm{x}$ & $\mathrm{x}$ & $\mathrm{x}$ & $\mathrm{x}$ & $\mathrm{x}$ & $\mathrm{x}$ \\
\hline 62 & Nymphalis polychloros (Linnaeus, 1758) & $\mathrm{x}$ & & $\mathrm{x}$ & $\mathrm{x}$ & $\mathrm{x}$ & & & & \\
\hline 63 & Nymphalis xanthomelas (Esper, 1781) & $\mathrm{x}$ & & $\mathrm{x}$ & $\mathrm{x}$ & $\mathrm{x}$ & & & & \\
\hline 64 & Euphydryas aurinia (Rottemburg, 1775) & & & & $\mathrm{x}$ & & & & & \\
\hline 65 & Melitaea cinxia (Linnaeus, 1758) & & $\mathrm{x}$ & & & & & & & \\
\hline 66 & Melitaea didyma (Esper, 1778) & & & & $\mathrm{x}$ & & & & & \\
\hline 67 & Melitaea diamina (Lang, 1789) & $\mathrm{x}$ & $\mathrm{x}$ & $\mathrm{x}$ & $\mathrm{x}$ & $\mathrm{x}$ & & & $\mathrm{x}$ & $\mathrm{x}$ \\
\hline 68 & Melitaea athalia (Rottemburg, 1775) & $\mathrm{x}$ & $\mathrm{x}$ & $\mathrm{x}$ & $\mathrm{x}$ & $\mathrm{x}$ & $\mathrm{x}$ & $\mathrm{x}$ & $\mathrm{x}$ & $\mathrm{x}$ \\
\hline 69 & Apatura iris (Linnaeus, 1758) & $\mathrm{x}$ & & & $\mathrm{x}$ & $\mathrm{x}$ & & & & \\
\hline 70 & Apatura ilia (Denis et Schiffermüller, 1775) & $\mathrm{x}$ & $\mathrm{x}$ & $\mathrm{x}$ & $\mathrm{x}$ & $\mathrm{x}$ & & $\mathrm{x}$ & & $x$ \\
\hline 71 & Pararge aegeria (Linnaeus, 1758) & $\mathrm{x}$ & $\mathrm{x}$ & $\mathrm{x}$ & $\mathrm{x}$ & $\mathrm{x}$ & $\mathrm{x}$ & $\mathrm{x}$ & $\mathrm{x}$ & $\mathrm{x}$ \\
\hline 72 & Lasiommata megera (Linnaeus, 1758) & $\mathrm{x}$ & & $\mathrm{x}$ & $\mathrm{x}$ & $\mathrm{x}$ & & & & \\
\hline 73 & Coenonympha arcania (Linnaeus, 1761) & $\mathrm{x}$ & $\mathrm{x}$ & $\mathrm{x}$ & $\mathrm{x}$ & $\mathrm{x}$ & & $\mathrm{x}$ & $\mathrm{x}$ & $\mathrm{x}$ \\
\hline 74 & Coenonympha glycerion (Borkhausen, 1788) & $\mathrm{x}$ & $\mathrm{x}$ & $\mathrm{x}$ & $\mathrm{x}$ & $\mathrm{x}$ & & & & $\mathrm{x}$ \\
\hline 75 & Coenonympha pamphilus (Linnaeus, 1758) & $\mathrm{x}$ & $\mathrm{x}$ & $\mathrm{x}$ & $\mathrm{x}$ & $\mathrm{x}$ & $\mathrm{x}$ & $\mathrm{x}$ & $\mathrm{x}$ & $\mathrm{x}$ \\
\hline 76 & Aphantopus hyperantus (Linnaeus, 1758) & $\mathrm{x}$ & $\mathrm{x}$ & $\mathrm{x}$ & $\mathrm{x}$ & $\mathrm{x}$ & $\mathrm{x}$ & $\mathrm{x}$ & $\mathrm{x}$ & $\mathrm{x}$ \\
\hline 77 & Maniola jurtina (Linnaeus, 1758) & $\mathrm{x}$ & $\mathrm{x}$ & $\mathrm{x}$ & $\mathrm{x}$ & $\mathrm{x}$ & $\mathrm{x}$ & $\mathrm{x}$ & $\mathrm{x}$ & $\mathrm{x}$ \\
\hline 78 & Hyponephele lycaon (Rottemburg, 1775) & $\mathrm{x}$ & & $\mathrm{x}$ & $\mathrm{x}$ & $\mathrm{x}$ & & & $\mathrm{x}$ & \\
\hline 79 & Melanargia galathea (Linnaeus, 1758) & & $\mathrm{x}$ & $\mathrm{x}$ & $\mathrm{x}$ & $\mathrm{x}$ & & & $\mathrm{x}$ & $\mathrm{x}$ \\
\hline 80 & Hipparchia semele (Linnaeus, 1758) & & & & $\mathrm{x}$ & & & & $\mathrm{x}$ & \\
\hline & Total number of recorded species & 54 & 54 & 65 & 69 & 62 & 25 & 29 & 49 & 46 \\
\hline
\end{tabular}

A few other species can still be found in the KNP, taking into consideration their distribution range in Poland, (e.g. Carcharodus silvicola (Meig.), Lycaena virgauarae (L.), Limenitis populi (L.), L. camilla (L.)). Some species are definitely much more widespread but under-recorded because of their habit, e.g. some Theclini like Neozephyrus querqus and Satyrium $w$-album spend most of the time in tree canopies. There are also still some inventory "blank spaces" on the map of the KNP, especially in the western part of the Park, which was the least intensively studied during our inventory work.

Lack of high quality historical inventory data makes any analyses of possible changes in distribution and abundance rather difficult. Taking into consideration the reliability of literature records, 89 species were recorded altogether from the present area of the KNP. Twenty one of them were found for the first time during our studies. However we were not able to confirm seven species mentioned by Patryn (1947) and two by Buszko (1997). Some details concerning selected Kampinos butterflies i.e. species extinct/rare in the Kampinos and/or threatened in Poland are presented in Table 2.

The presence of three of the previously recorded species not confirmed in our survey i.e. Pyrgus alveus (Hbn.), Lasiommata maera (L.) and Erebia medusa (Den. et Schiff.), 
mesophilous species inhabiting clearings and forest edges, is still likely. However, Colias myrmidone (Esp.), Pseudophilotes vicrama (Moore), Hipparchia statilinus (Hufn.) and $H$. alcyone (Den. et Schiff.), observed by Patryn (1947), have probably become extinct in the KNP. All these species are endangered or vulnerable in Poland. They are encountered on dry heaths or xerothermic grasslands. In the KNP these types of vegetation are related to dunes and they are disappearing due to afforestation or spontaneous succession. C. myrmidone, a Habitat Directive species, whose larvae develop on Chamaecytisus Link., has seriously declined in the whole country very recently. As far as Melitaea aurelia Nick. is concerned, Patryn (1947) unfortunately did not describe sites of the butterfly in the KNP. The species is known from two contrasting types of habitats in Central Europe i.e. damp meadows and dry grasslands (Settele et al. 1999, Beneš et al. 2002, Buszko \& Masłowski 2008) and therefore it is hardly possible to draw any conclusions about the reasons of its extinction in the Kampinos Forest.

Table 2. Rare and threatened butterflies in the Kampinos National Park. R - recorded by: 1 - the authors, 2 - Buszko (1997), 3 - Patryn (1947); B - biotope classification (Settele et al. 1999, Beneš et al. 2002; adapted to Polish conditions): X1 - xerothermophilous species of non-wooded areas e.g. dry grasslands and heathlands, X2 xerothermophilous species preferring sites with longer sward and some proportions of shrubs and trees, M1 - species of open habitats especially of mesic meadows, M2 - mesophilous species of clearings, forest edges etc., M3 woodland species, $\mathrm{H}$ - higrophilous species inhabiting fens, litter meadows, tall herbs and other eutrophic wetlands, $\mathrm{U}$ - generalists; KNP - estimated status in the KNP; PL - national status (Buszko \& Nowacki 2002), * species protected by law in Poland; EU - conservational status in Europe (van Swaay \& Warren 1999); HD - presence in appendixes of Habitats' Directive.

\begin{tabular}{|c|c|c|c|c|c|c|}
\hline Butterfly species & $\mathrm{R}$ & $\mathrm{B}$ & KNP & $\mathrm{PL}^{*}$ & $\mathrm{EU}$ & $\mathrm{HD}$ \\
\hline Pyrgus alveus (Hbn.) & 3 & M2 & EX? & & & \\
\hline Iphiclides podalinius (L.) & 1 & $\mathrm{X} 2$ & DD & VU* & & \\
\hline Colias myrmidone (Esp.) & 3 & $\mathrm{X} 2$ & $\mathrm{EX} ?$ & VU* & $\mathrm{VU}$ & II, IV \\
\hline Leptidea sinapis (L.) & 3 & $\mathrm{X} 2, \mathrm{M} 2$ & EX? & & & \\
\hline Lycaena helle (Den. et Schiff.) & 1 & $\mathrm{H}$ & $\mathrm{CR}$ & VU* & VU & II, IV \\
\hline Lycaena dispar (Haw.) & 1,3 & $\mathrm{H}$ & $\mathrm{LC}$ & $\mathrm{LC}^{*}$ & & II, IV \\
\hline Cupido minimus (Fuessly) & 1 & $\mathrm{X} 1$ & $\mathrm{DD}$ & & & \\
\hline Pseudophilotes vicrama (Moore) & 3 & $\mathrm{X} 1$ & $\mathrm{EX} ?$ & $\mathrm{EN}$ & VU & \\
\hline Maculinea arion (L.) & $1,2,3$ & $\mathrm{X} 1, \mathrm{X} 2$ & $\mathrm{CR}$ & $\mathrm{EN}^{*}$ & $\mathrm{EN}$ & IV \\
\hline Maculinea alcon (Den. et Schiff.) & 1 & $\mathrm{H}$ & vU & VU* & $\mathrm{VU}$ & \\
\hline Maculinea nausithous (Bgstr.) & 1 & $\mathrm{H}$ & $\mathrm{EX} ?$ & $\mathrm{LC}^{*}$ & $\mathrm{VU}$ & II, IV \\
\hline Maculinea teleius (Bgstr.) & 1,2 & $\mathrm{H}$ & NT & $\mathrm{LC}^{*}$ & VU & II, IV \\
\hline Plebejus argus (L.) & $1,2,3$ & $\mathrm{X} 1$ & VU & & & \\
\hline Aricia agestis (Den. et Schiff.) & 1 & $\mathrm{X} 1$ & VU & & & \\
\hline Polyommatus coridon (Poda) & 1 & $\mathrm{X} 1$ & vU & & & \\
\hline Argymmis addipe (Den. et Schiff.) & 1 & M2 & DD & & & \\
\hline Argynnis laodice (Pall.) & 1 & $\mathrm{~T}$ & $\mathrm{DD}$ & & & \\
\hline Euphydryas aurinia (Rott.) & 1 & $\mathrm{H}$ & $\mathrm{CR}$ & $\mathrm{EN} *$ & VU & II \\
\hline Melitaea cinxia (L.) & 1,2 & M1 & $\mathrm{DD}$ & & & \\
\hline Melitaea didyma (Esp.) & 1,3 & $\mathrm{X} 1$ & vU & VU & & \\
\hline Melitaea diamina (Lang.) & 1 & $\mathrm{H}$ & LC & VU & & \\
\hline Melitaea aurelia Nick. & 3 & $\mathrm{X} 1$ & $\mathrm{EX} ?$ & EN & VU & \\
\hline Nymphalis xanthomelas (Esp.) & 1 & M3 & $\mathrm{LC}$ & DD & $\mathrm{VU}$ & \\
\hline Lasiommata maera (L.) & 2 & $\mathrm{M} 3, \mathrm{X} 2$ & EX? & & & \\
\hline Erebia medusa (Den. et Schiff.) & 2 & M2 & EX? & & $\mathrm{VU}$ & \\
\hline Hipparchia statilimus (Hufn.) & 3 & $\mathrm{X} 1$ & $\mathrm{EX} ?$ & VU & & \\
\hline Hipparchia alcyone (Den. et Schiff.) & 3 & $\mathrm{X} 2$ & EX? & $\mathrm{EN}^{*}$ & & \\
\hline
\end{tabular}

As far Leptidea sinapis (L.) is concerned the certain determination is possible only if genitalia are examined. A specimen collected by Patryn (1947) was dissected and identified as L. sinapis by Sachanowicz (unpublished). L. sinapis is a declining species and it was recorded recently only from north-eastern and southern parts of Poland. it also seems to prefer drier habitats compare to its widespread close relative L. reali (Buszko \& Masłowski 2008). 
However, although all our specimens were determined as L. reali, a large sample is required to exclude the presence of $L$. sinapis in the KNP nowadays.

Applying categorisation used by Settele et al. (1999), slightly modified to Polish conditions, 18 of the species recorded during present studies can be classified as ubiquitous (eurytopic) butterflies observed in various habitats and several of them e.g. Pieris rapae (L.), P. napi (L.), Inachis io (L.), Coenonympha pamphilus (L.) and Maniola jurtina (L.) belong to the most frequently observed butterflies.

Only 11 butterfly species found in the KNP are woodland specialists i.e. Neozephyrus quercus (L.), Satyrium w-album (Knoch), Celastrina argiolus (L.), Argynnis paphia (L.), Polygonia c-album (L.), Nymphalis antiopa (L.), N. polychloros (L.), N. xanthomelas (Esp.), Apatura ilia (Den. et Schiff.), A. iris (L.) and Pararge aegeria (L.). The most interesting of them is probably $N$. xanthomelas which, according to Buszko \& Masłowski (2008), does not establish a constant population in Poland. In the Kampinos Forest it had been observed regularly in low numbers throughout the whole period of studies in four UTM squares.

Dunes are the habitats of some stenotopic xerothermophilous species. The most interesting of them is probably Maculinea arion (L.) which is threatened in Europe and seriously declining in Poland (Sielezniew et al. 2005). It still thrives in the KNP but it was recorded from just a single locality near Truskaw (DC 69). In the late 1990's it was also observed in DC 99 (Kowalski pers. comm.) and earlier in DC 69 by Patryn (1947). Females of $M$. arion lay their eggs on flowerheads of Thymus serpyllum $\mathrm{L}$. The initially phytophagous caterpillars spend their final instar in nests of specific Myrmica Latr. ants, feeding upon their brood. At a site of $M$. arion in the KNP we observed $M$. schencki Em. in the turf, which according to recent studies in NE Poland is a potential host of the butterfly (Sielezniew \& Stankiewicz 2008). Ecological niches of Myrmica ants are much narrower compared to the requirements of the larval food plant. Overgrowth of clearings and dropping of the water table level are probably the most important negative factors affecting populations of red ants which avoid very dry soil conditions.

Successional closure of dunes is probably also the reason for the rarity of some other species such as Melitaea didyma (Esp.) (host plants: Verbascum L., Veronica L. and some other herbs) recorded exclusively at the $M$. arion site. The butterfly is vulnerable on a national scale as well (Buszko \& Nowacki 2002). Other stenotopic butterflies related to open dry vegetation were Hyponephele lycaon (Den. et Schiff.) and Hipparchia semele (L.), whose larvae feeds on some grasses, especially on Festuca L. and Bromus L.

On the other hand, short-sward steppe grasslands can be also initially replaced by heather Calluna vulgaris $\mathrm{L}$., which is used by caterpillars of two distinctive and locally abundant blues, representatives of the genus Plebejus Kluk. P. idas (L.) was found at three sites (DC 79, DC 89, DD 70) and $P$. argus (L.) only on one locality (DC 89). This discrepancy is probably related to differences in their microhabitat preferences. Both species are obligatorily myrmecophilous and their relationships with ants are mutual (Fiedler 2006). We observed numerous caterpillars of $P$. idas accompanied by Formica cinerea Mayr. workers. However, $P$. argus is related exclusively to Lasius niger (L.) and $L$. alienus (Först.) which were probably much rarer, or absent, in the very dry sandy habitats dominated by $F$. cinerea. We found both Plebejus butterflies only at one locality where the area overgrown by heather was relatively the most diverse in terms of humidity.

Other types of warm grassland support other xerothermophilous lycenid butterflies rarely observed in the KNP. Cupido minimus (Fuessly) (larvae feed on Anthyllis vulneraria L.) and Polyommatus coridon (Poda) (Coronilla varia L.) were recorded at just one site in DC 99 and Aricia agestis (Den. et Schiff.) (Geranium L. and some other herbs) was observed in DC 79 and DC 89. 
Iphiclides podalirius (L.) is a forest-steppe species and it was observed during our studies only once, in DC 99. However it was also recorded in DC 89 by Davies (pers. comm.) in 2007. In the vicinity of Warsaw the species occurs much more frequently on the right bank of the Vistula river (Winiarska 2003).

Mesophilous species were generally common in the KNP, with most frequently recorded species like: Thymelicus lineola (Ochs.), T. sylvestris (Poda), Ochlodes sylvanus (Esp.), Lycaena tityrus (Poda), Argynnis aglaja (L.), Araschnia levana (L.), Coenonympha arcania (L.) and Aphantopus hyperantus (L.). However, a few butterflies preferring mesic open meadows have probably declined. Melitaea cinxia (L.), whose larvae are related to Plantago L. and Veronica L. used to be a common species in the eastern part of the KNP (DC 59) in 1989 (Buszko 1997, Sielezniew unpublished), but its presence there has not been confirmed so far. During the recent inventory work the butterfly was found at just one site near the south-west border of the park (DC 89).

The absence of tyrphophilous species is a characteristic feature of the butterfly fauna of the KNP. We checked the only raised bog in the Kampinos Forest, and we did not observe the butterflies typically related to such habitat, like Colias palaeno (L.), Vaccinium optilete (Knoch.) and Boloria aquilonaris (Stich.). We did not find Coenonympha tullia (Müll.) either, whose host plants, i.e. Eriophorum L. can be found in fen communities.

However, higrophilous butterflies preferring eutrophic wetlands are represented relatively numerously. They include several species listed in the European Red Data Book (van Swaay \& Warren 1999) and/or the Red list of threatened animals in Poland (Buszko \& Nowacki 2002). Four species were quite widespread on meadows in the KNP and they were recorded in seven UTM squares. Heteropterus morpheus (Pall.) is a typical higrophilous grassland species, whose larvae feed among others on Molinia caerulea L. The double brooded Lycaena dispar (Haw.) usually appeared in low densities and it was recorded throughout the KNP in seven UTM squares. The larval host plants e.g. Rumex hydrolapathum Huds. and $R$. obtusifolius L. grow along drainage ditches and therefore the species does not tend to need special conservation measures. In tall herb communities with Valeriana officinalis L., Melitaea diamina (Lang.) was regularly observed, but in lower numbers. Brenthis ino (Rott.) was a much more frequently recorded species. Filipendula ulmaria L. and Sanguisorba officinalis L. are larval food plants of this not endangered but very characteristic higrophilous butterfly, very rarely observed out of litter meadows and tall herb communities.

Maculinea teleius (Bgstr.) belonged to the most often encountered butterflies on litter meadows in July and August, and it was recorded at ten sites from six UTM squares. It became extinct in DC 99 where it was observed by Kowalski in the late 1990's. (pers. comm.). Nearly all patches where Sanguisorba officinalis grew numerously were occupied. $M$. teleius, like $M$. arion and other Maculinea species, is obligatorily myrmecophilous and specific red ants are needed to for the completion of its development. Caterpillars of $M$. teleius develop in both Myrmica rubra (L.), M. scabrinodis Nyl. and M. gallienii Bondr. colonies (Stankiewicz \& Sielezniew 2002), which were quite common in extensively used or recently abandoned meadows. Longer abandonment, drainage and eutrophication cause the local decline of the butterfly following the disappearance of host-plants and host-ants. Former litter meadows become overgrown by shrubs, invasive goldenrod Solidago canadensis L. or stinging nettle Urtica dioica L. Conservation of the populations of $M$. teleius in the KNP is especially important because they are in the northern distribution range in Poland (Buszko et al. 2005). Its close relative $M$. nausithous (Bgstr.), which uses the same host plant, was recorded only in 2005 from one of the sites shared with $M$. teleius (DC 79). We hypothesize that $M$. nausithous has become extinct there. It may be related to its high specificity to M. rubra (Stankiewicz \& Sielezniew 2002) which is not a dominant species at the site (Dziekańska \& Sielezniew 
unpublished). On the other hand in central and eastern Poland $M$. teleius is usually much more frequently recorded and common than $M$. nausithous (Buszko et al. 2005).

The third higrophilous Maculinea species, $M$. alcon (Den. et Schiff.) was recorded at seven sites in five UTM squares. This butterfly in Mazovia is dependent on Gentiana pnemonanthe L. and M. scabrinodis (Sielezniew \& Stankiewicz 2002). M. alcon eggs are easy to record as they are laid mainly on the outer parts of flower buds and young leaves. After hatching, larvae bore into flower heads, but the eggshells remain and are very persistent. Assessment of the population size can be made this way quite easily. Observations suggest that in almost all localities in the KNP, just a dozen or so imagines are on the wing every year, and just one site supports a relatively big and therefore relatively safe population of adults. $G$. pneumonanthe is very widespread in the KNP but not all meadows with the plant are occupied. In some cases over intensive management probably makes those patches inappropriate for $M$. alcon. Too early mowing prevents oviposition and heavy machines make the turf unpleasant for Myrmica ants, which prefer distinctive tussocks of grass for the establishment of their colonies.

Lycaena helle (Den. et Schiff.) was found at only one site, in close proximity to meadows where $M$. alcon, $M$. teleius and $M$. nausithous were recorded (DC 79). The butterfly was the most common in a sheltered area which had been unmown for at least three years, but its larval food plant Polygonum bistorta L. still occurred in high density. For this small butterfly the overall architecture of vegetation, as well as the presence of $P$. bistorta, is vital. Bushes or trees forming a wall or scattered throughout a meadow ensure the resting and basking places especially important for territorial males (Fischer et al. 1999).

Euphydryas aurinia (Rott.) is one of the most endangered of all the butterfly species recently recorded in the KNP. A site in the eastern part of the park (DC 69) is the only one known in Mazovia, and therefore probably highly isolated. Just a few adults were observed and specimens with crumpled wings were present, which may indicate inbreeding depression. Although the host plant Succisa pratensis Moench. is quite common there, the vegetation structure probably does not provide proper micro-climatic conditions for the butterfly, especially not for the development of heliophilous larvae. Females carefully select oviposition places and batches of eggs are laid on the leaves of shapely plants growing in warmer places, which is important for the basking behaviour of caterpillars in the early spring (Palka 2007). The meadow is overgrown at the moment and urgent action is needed to restore the optimal habitat of E. aurinia.

\section{CONCLUSIONS}

The high diversity of butterflies recorded in the Kampinos National Park, as well as the presence of species threatened on a European, national or regional scale, make it possible to consider this area as an important stronghold for butterflies at least in the Mazovia region. Therefore, the KNP deserves to be added to the Polish Prime Butterfly Areas, encompassing 16 localities at the moment (Buszko 2003). However, during our studies we also identified potential threats for some species resulting from abandonment or wrong management. Conservation of the diversity of the Kampinos butterflies should take into account the requirements of priority butterfly species, but it is impossible to propose uniform management for all of them. However, although ecological succession is the main problem, except some cases where quick action is needed, all intensifications should be done very carefully. Single mowing of the whole habitat with heavy machines in the sensitive period of the life cycle can be much more destructive than abandonment for years. In 2007 a 3-year long Life-Nature project, aimed at the conservation of the threatened higrophilous butterfly species of the Habitats' Directive, was initiated in the Park, which was one of three project areas. The main 
objective of the project is to restore or improve habitats by bush removal and mowing. However, a long term conservation strategy must be realized by the KNP to save the high diversity of butterflies.

\section{ACKNOWLEDGEMENTS}

I. Dziekańska is very grateful to Maria Dziekańska and especially to Jan Dziekański for their support during field studies. We are indebted to Marek Kowalski who made his records, collected in late 1990's (especially of threatened species), available. Anna Matysiak provided us with her record on $M$. alcon, and Stephen Davies and Marcin Mikusek on Iphiclides podalirius. Jakub Łodyga also forwarded additional information on butterflies encountered in the vicinity of the Kampinos Forest. Konrad Sachanowicz determined collected specimens of Leptidea reali and provided us with information about the identity of a $L$. sinapis specimen collected by Patryn (1947). The director of the KNP kindly gave his permission for us to perform the present studies. M. Sielezniew was supported by the Ministry of Science and Higher Education (grant no 2 P04G 024 30).

\section{REFERENCES}

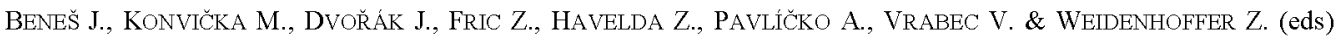
2002. Motýli České republiky: Rozšírení a ochrana, I., II. SOM, Praha, 857 pp [in Czech]

BUSZKO J. 1997. A distribution atlas of butterflies in Poland 1986-1995. Turpress, Torun, $170 \mathrm{pp}$.

Buszko J. 2003. Poland. In: VAN SwAAY C. A. M. \& WARREN M. S. (eds), Prime Butterfly Areas in Europe: priority sites for conservation, pp. 399-401. Ministry of Agriculture, Nature Management and Fisheries, The Netherlands, $695 \mathrm{pp}$.

Buszko J., Kokot A., PAlik E. \& Śliwtíski Z. 1996. Motyle większe (Macrolepidoptera) Puszczy Białowieskiej. Parki Narodowe i Rezerwaty Przyrody 15: 3-46.

Buszko J. \& MASŁ.OWSKI J. 2008. Motyle Dzienne Polski. Wydawnictwo Koliber, Nowy Sącz, 274 pp.

BUSZKO J. \& NowACKI J. 2000. (eds) The Lepidoptera of Poland. A Distributional Checklist. Polish Entomological Monographs Vol. 1. Polskie Towarzystwo Entomologiczne, Poznań-Toruń, 178 pp.

BuszKo J. \& NowACKI J. 2002. Lepidoptera Motyle. In: GŁoWACIŃski Z. (ed.), Czerwona Lista Zwierząt Ginących i Zagrożonych w Polsce, pp. 80-87. Kraków, Instytut Ochrony Przyrody PAN, 155 pp.

Buszko J., Sielezniew M. \& Stankiewicz A.M. 2005. The distribution and ecology of Maculinea teleius and $M$. nausithous in Poland. In: SETTELE J., KÜHN E. \& THOMAS J.A. (eds), Studies on the Ecology and Conservation of Butterflies in Europe. Vol. 2: Species Ecology along a European Gradient: Maculinea butterflies as a Model, pp. 210-213. Pensoft Publishers, Sofia-Moscow, 289 pp.

FIEDLER K. 2006. Ant-associates of Palearctic lycaenid butterfly larvae (Hymenoptera: Formicidae; Lepidoptera: Lycaenidae) - a review. Myrmecologische Nachrichten 9: 77-87.

FISCHER K., BEINLICH B. \& PLACHTER H. 1999. Population structure, mobility and habitat preferences of the Violet Copper Lycaena helle (Lepidoptera: Lycaenidae) - implications for conservation. Journal of Insect Conservation 3: $43-52$.

FRĄCKIEL K. 1999. Motyle dzienne (Lepidoptera: Papilionoidea, Hesperioidea) Biebrzańskiego Parku Narodowego. Wiadomości Entomologiczne 18: 85-98.

HEYMANOWSKI K. 1966. Dzieje Puszczy Kampinoskiej do połowy XIX wieku. Sylwan 110: 1-15.

KLIMCZUK P. \& Twerd J. 2000. Motyle dzienne (Papilionoidea i Hesperioidea) Puszezy Knyszyńskiej i okolic Białegostoku. Parki Narodowe i Rezerwaty Przyrody 19: 85-97.

KobendZA J. 1930. Stosunki fitosocjologiczne w Puszczy Kampinoskiej. Planta Polonica 2: 1-200.

KudeA W. \& WoJTUSIAK J. 2004. Butterflies (Lepidoptera, Rhopalocera) of the Blędów Desert and neighbouring area in the Olkusz District, Poland. Fragmenta Faunistica 47: 65-71.

MATYSIAK A. 2007. Porównanie roślinności terenów porolnych zalesionych i pozostawionych naturalnej sukcesji $\mathrm{w}$ Kampinoskim Parku Narodowym. Przegląd Przyrodniczy 18 (1-2): 109-191.

MiCHALSKA-HEJDUK D. 2001. Stan obecny i kierunki zmian roślinności nieleśnej Kampinoskiego Parku Narodowego. Monographiae botanicae 89: 1-134.

MichalsKa-HeJduK D. 2006. Zmiany w zbiorowiskach nieleśnych Kampinoskiego Parku Narodowego. Puszcza Kampinoska 4: 11-14.

Palik E, Przybyeowicz L., Kosior A., Król W., Solarz W. \& WitKowski Z. 2005. Changes in the species composition and distribution of butterflies (Rhopalocera) in Cracow (Poland) since the mid-19th century. Fragmenta Faunistica 48: 181-215. 
PALKA K. 2007. Krajowy plan zarządzania gatunkiem - przeplatka aurinia Euphydras aurinia; http://natura2000.mos.gov.pl

PATRYN W. 1947. Spis motyli dziennych i nocnych zebranych w okolicach Warszawy. Materiały do Fizjografii Kraju, Kraków, 5: 1-50.

POLLARD E. \& YATES T. J. 1993. Monitoring Butterflies for Ecology and Conservation. Chapman \& Hall, London, $274 \mathrm{p}$.

Settele J., Feldmann R. \& Reinhardt R. (eds) 2000. Die Tagfalter Deutschlands. Ulmer, Stuttgart. 450 pp.

SIELEZNIEW M. \& STANKIEWICZ A. 2002. First data on host-ant specificity of parasitic butterfly Maculinea alcon (Den. et Schiff.) (Lepidoptera: Lycaenidae) in Poland and eastern Europe. Fragmenta Faunistica 45: 123-130.

SIELEZNIEW M. 2001. Motyle dzienne (Rhopalocera) okolic Skarpy Ursynowskiej w Warszawie: skład gatunkowy i monitoring ilościowy. In: INDYKIEWICZ P., BARCZAK T., KACZOROWSKI G. (eds), Bioróżnorodność i ekologia populacji zwierzęcych w środowiskach zurbanizowanych, pp. 82-88. NICE. Bydgoszcz, 297 pp.

SIELEZNIEW M., BUSZKO J. \& STANKIEWICZ A. M. 2005. Maculinea arion in Poland: distribution, ecology and prospects of conservation. In: SETTELE J., KÜHN E. \& THOMAS J. A. (eds), Studies on the Ecology and Conservation of Butterflies in Europe. Vol. 2. Species Ecology along a European Gradient: Maculinea butterflies as a Model, pp. 231-233. Pensoft Publishers, Sofia-Moscow, 289 pp.

SiElezNIEW M. \& Sachanowicz K. 2003. Motyle dzienne (Lepidoptera i Hesperioidea) Puszczy Rominckiej wyniki badań wstępnych. Parki Narodowe i Rezerwaty Przyrody 22: 581-592.

SIELEZNIEW M. \& STANKIEWICZ A. M. 2008. Myrmica sabuleti (Hymenoptera: Formicidae) not necessary for the survival of the population of Phengaris (Maculinea) arion (Lepidoptera: Lycaenidae) in eastern Poland: lower host-ant specificity or evidence for geographical variation of an endangered social parasite? European Journal of Entomology 105: 637-641.

STANKIEWICZ A. \& SIELEZnIEW M. 2002. Host specificity of Maculinea teleius Bgstr. and M. nausithous Bgstr. (Lepidoptera: Lycaenidae). The new insight. Annales Zoologici 53: 403-409.

SWAAY C. A. M. VAN \& WARREN M. S. 1999. Red Data Book of European butterflies (Rhopalocera). Nature and Environment, No 99. Council of Europe Publishing, Strasbourg, $260 \mathrm{pp}$.

WINIARSKA G. 2001. Butterflies (Lepidoptera: Hesperioidea, Papilionoidea) in Narew National Park. Fragmenta Faunistica 44: 73-78.

WINIARSKA G. 2003. Butterflies and moths (Lepidoptera) in urban habitats: II The butterflies (Rhopalocera) of Warsaw. Fragmenta Faunistica 46: 56-67.

\section{STRESZCZENIE}

\section{[Tytul: Motyle dzienne (Papilionoidea i Hesperioidea) Kampinoskiego Parku Narodowego]}

Kampinoski Park Narodowy jest drugim pod względem wielkości obszarem chronionym w Polsce i stąd ważną ostoją różnorodności biologicznej w skali kraju i Mazowsza. Pomimo sąsiedztwa warszawskiego ośrodka akademickiego, pozostaje jednak terenem słabo zbadanym pod względem fauny bezkręgowców, czego przykładem mogly być przez dhugi czas motyle dzienne (Papilionoidea i Hesperioidea). Wschodnie częśsi parku były eksplorowane przez Patryna (1947), który wlączył dane dotyczące 40 gatunków do spisu motyli zebranych w okolicach Warszawy. Natomiast, analizując informacje zawarte w „Atlasie rozmieszczenia motyli dziennych w Polsce 1986-1995" można wysnuć wniosek o stwierdzeniu 54 gatunków w kwadratach UTM $(10 \times 10 \mathrm{~km})$ pokrywających się z terenem Puszczy Kampinoskiej (Buszko 1997).

W czasie badan inwentaryzacyjnych prowadzonych w latach 2005-2008 obejmujących 9 puszczańskich kwadratów siatki UTM, stwierdziliśmy obecność 80 gatunków tj. 81,6\% motyli dziennych woj. mazowieckiego oraz połowę krajowej fauny tej grupy. W sumie z terenu Parku wykazano do tej pory 89 gatunków. Szereg gatunków kserotermofilnych prawdopodobnie wyginęlo w ostatnich dekadach $\mathrm{tj}$. Colias myrmidone (Esp.), Pseudophilotes vicrama (Moore), Melitaea aurelia Nick., Hipparchia statilinus (Hufn.), H. alcyone (Den. et Schiff.) lub też jest zagrożona wyginięciem w skali Parku lub regionu jak Maculinea arion (L.) i Melitaea didyma (Esp.) z powodu zalesiania lub naturalnej sukcesji. Fauna motyli higrofilnych generalnie mniej ucierpiała pod wplywem ostatnich zmian użytkowania, ale konieczne są działania mające na celu powstrzymanie obserwowanej degradacji ich siedlisk. Lycaena dispar (Haw.), Maculinea 
teleius (Bgstr.) i $M$. alcon (Den. et Schiff.) są wciąż relatywnie rozprzestrzenione ale $L$. helle (Den. et Schiff.) i Euphydryas aurinia (Rott.) zostaly znalezione tylko na pojedynczych stanowiskach. $Z$ kolei $M$. nausithous (Bgstr.) był obserwowany tylko w 2005 r. i nie można wykluczyć, że byliśmy świadkami jego zniknięcia z terenu KPN.

Spośród gatunków znalezionych w czasie ostatniej inwentaryzacji 7 figuruje w Europejskiej Czerwonej Księdze Motyli (van Swaay \& Warren 1999), 15 na Polskiej Czerwonej Liście Zwierząt Ginących i Zagrożonych (Buszko i Nowacki 2002), a 8 znajduje się pod ochrona prawną w naszym kraju. W związu z tym Puszcza Kampinoska powinna naszym zdaniem dołączyć do 16 polskich Obszarów o Znaczeniu Pierwszorzędnym dla Motyli (Prime Butterfly Areas) (Buszko 2003).

Accepted: 16 December 2008 